\title{
PENGARUH KEPEMIMPINAN VISIONER DAN PEMBERDAYAAN PEGAWAI TERHADAP KINERJA PEGAWAI DI DINAS TATA RUANG DAN PERMUKIMAN KABUPATEN CIANJUR (Studi Terhadap Persepsi Pegawai di Lingkungan Distarkim Kab. Cianjur)
}

\author{
Warsidi \\ Mahasiswa Magister Manajemen Bisnis Sekolah Pasca Sarjana Univeritas Pendidikan Indonesia
}

\begin{abstract}
ABSTRAK
Dinas Tata Ruang dan Permukiman merupakan unsur pelaksana otonomi daerah di bidang tata ruang, bangunan, perumahan dan permukiman, air bersih dan teknik penyehatan lingkungan, dipimpin oleh seorang Kepala Dinas yang berada di bawah dan bertanggungjawab kepada Bupati melalui Sekretaris Daerah. Dinas Tata Ruang dan Permukiman mempunyai tugas melaksanakan sebagai urusan pemerintah daerah di bidang penataan ruang, bangunan, perumahan dan permukiman, air bersih dan teknik penyehatan lingkungan pemukiman berdasarkan azaz otonomi dan tugas pembantuan. Tujuan penelitian ini ialah untuk mendeskripsikan kepemimpinan visioner, pemberdayaan pegawai, dan kinerja pegawai, serta bagaimana hubungan dan pengaruh diantara variabel kepemimpinan visioner, pemberdayaan pegawai, dan kinerja pegawai Dinas Tata Ruang dan Permukiman Kabupaten Cianjur.

Metode penelitian yang digunakan adalah deskriptif dan eksplanatori survei. Teknik sampel yang digunakan berupa simple random sampling (SRS). Teknik pengumpulan data antara lain dengan cara penyebaran angket (kuesioner), wawancara terbatas, dan observasi. Alat pengumpulan data berupa angket. Teknik analisis data menggunakan analisis regresi.

Berdasarkan hasil penelitian, dapat disimpulkan bahwa hubungan kepemimpinan visioner dan pemberdayaan pegawai dengan kinerja pegawai bersifat positif. Makna hubungan positif disini adalah jika kepemimpinan visioner dan pemberdayaan pegawai meningkat, maka kinerja pegawai di Distarkim Kab. Cianjur juga akan meningkat. Kepemimpinan visioner berpengaruh positif dan signifikan terhadap kinerja pegawai di Distarkim Kab. Cianjur. Pemberdayaan pegawai berpengaruh positif dan signifikan terhadap kinerja pegawai di Distarkim Kab. Cianjur. Kepemimpinan visioner dan pemberdayaan pegawai berpengaruh positif dan signifikan terhadap kinerja pegawai di Distarkim Kab. Cianjur. Faktor lain yang diduga turut mempengaruhi penelitian ini misalnya budaya organisasi, kompetensi kerja pegawai, dan pelatihan kerja.
\end{abstract}

Kata Kunci : Kepemimpinan Visioner, Kinerja Pegawai, Pemberdayaan Pegawai

\section{PENDAHULUAN}

Dunia yang semakin menyatu dalam satu kesatuan yang utuh melalui globalisasi sudah menjadi kenyataan. Thomas L. Friedman bahkan merangkumnya dengan bahasa yang lugas: "The World is Flat". Globalisasi sendiri menurut Thomas Friedman (2009) bergeser dari Globalization 1.0 menuju Globalization 2.0, dan sekarang Globalization 3.0. Saat ini, bukan saja isu perekonomian dan perdagangan dunia yang kian menyatu, namun juga berbagai isu lain, seperti demokratisasi, ilmu pengetahuan, teknologi, komunikasi dan informasi, bahkan pendidikan, serta berbagai isu lainnya. Berbagai negara membentuk aliansi bersama untuk bergabung dalam satu kekuatan besar dalam menghadapi persaingan yang semakin kompetitif. Sehingga batasan suatu negara kian tak kentara dengan tingkat dinamika dan mobilitas yang semakin tinggi dari masyarakatnya.

Dalam konteks persaingan global, World Competitiveness Yearbook tahun 2006-2008 mencatat daya saing Indonesia turun ke peringkat 51 dari 55 negara. Sementara dari World Economic Forum, daya saing Indonesia menduduki peringkat ke-54, di bawah negara-negara lain di kawasan Asia Tenggara seperti Singapura, Malaysia, dan Thailand. Berdasarkan hal tersebut, diketahui bahwa daya saing Indonesia masih lemah dibandingkan dengan negara-negara lainnya di 
dunia, bahkan lebih rendah dibandingkan negara mitra di kawasan asia tenggara (ASEAN). Untuk meningkatkan daya saing, Indonesia mesti membangun dan mengembangkan sumber daya manusia (SDM) multi keterampilan dan talenta, karena SDM merupakan salah satu modal intelektual dalam bersaing di era global. Di era globalisasi, hanya negara yang mampu menyediakan dan mengembangkan SDM yang akan mampu bersaing dengan negara lain, dalam hal ini maka SDM perlu dikelola dengan baik dengan mengimplementasikan fungsi-fungsi manajemen modern, disinilah pentingnya manajemen SDM bagi setiap organisasi.

Manajemen sumber daya manusia (MSDM) merupakan salah satu bidang dari manajemen umum yang meliputi segi-segi perencanaan, pengorganisasian, pelaksanaan, pengendalian, dan pengawasan. Proses ini terdapat dalam fungsi atau bidang produksi, pemasaran, keuangan, maupun kepegawaian. Dalam usaha pencapaian tujuan organisasi, permasalahan yang dihadapi manajemen bukan hanya terdapat pada bahan mentah, alat-alat kerja saja, tetapi juga menyangkut pegawai (sumber daya manusia) yang mengelola faktor-faktor lainnya tersebut.

Unsur dalam manajemen adalah tenaga kerja pada suatu organisasi, sehingga dalam Manajemen SDM faktor yang diperhatikan adalah manusianya itu sendiri. Saat ini banyak organisasi menyadari bahwa SDM merupakan masalah organisasi yang paling penting, karena melalui sumber daya manusialah yang menyebabkan sumber daya yang lain dalam organisasi dapat berfungsi atau dijalankan. Peran manajemen SDM dalam menjalankan aspek SDM, harus dikelola dengan baik sehingga kebijakan dan praktek dapat berjalan sesuai dengan yang diinginkan organisasi, yang meliputi kegiatan antara lain: melakukan analisis jabatan, merencanakan kebutuhan tenaga kerja dan merekrut calon pekerja, menyeleksi calon pekerja, melakukan evaluasi kinerja, dan lain-lain.

Kinerja merupakan hasil akhir dari suatu pekerjaan atau aktivitas tertentu. Apabila kita melakukan suatu pekerjaan dengan baik, maka kita akan menghasikan kinerja yang baik pula. Dalam sebuah organisasi apabila kinerja pegawai baik, maka akan menciptakan kinerja organisasi yang baik, dan sebaliknya apabila kinerja pegawai kurang baik, hal ini akan membentuk kinerja organisasi yang kurang baik juga. Mangkunegara (2007:67) mengemukakan kinerja adalah hasil kerja secara kualitas dan kuantitas yang dicapai oleh seorang pegawai dalam melaksanakan tugasnya sesuai dengan tanggung jawab yang diberikan kepadanya.

Dinas Tata Ruang dan Permukiman merupakan unsur pelaksana otonomi daerah di bidang tata ruang, bangunan, perumahan dan permukiman, air bersih dan teknik penyehatan lingkungan, dipimpin oleh seorang Kepala Dinas yang berada di bawah dan bertanggungjawab kepada Bupati melalui Sekretaris Daerah. Dinas Tata Ruang dan Permukiman mempunyai tugas melaksanakan sebagai urusan pemerintah daerah di bidang penataan ruang, bangunan, perumahan dan permukiman, air bersih dan teknik penyehatan lingkungan pemukiman berdasarkan azaz otonomi dan tugas pembantuan. Dalam melaksanakan tugas sebagaimana dimaksud diatas, Dinas Tata Ruang dan Permukiman, menyelenggarakan fungsi:

1. Perumusan kebijakan teknis dinas di bidang perencanaan, pelaksanaan, pembinaan, evaluasi dan lapoan penyelenggara sebagai urusan pemerintah di bidang tata ruang, bangunan, perumuhan, dan permukiman, air bersih dan teknis penyehatan lingkungan sesuai dengan ketentuan dan/atau peraturan perundang-undangan yang berlaku;

2. Penyelenggaraan urusan pemerintah dan pelayanan umum di bidang tata ruang, bangunan, perumuhan, dan permukiman, air bersih dan teknis penyehatan lingkungan sesuai dengan ketentuan dan/atau peraturan perundang-undangan yang berlaku;

3. Pembinaan dan Pelaksanaan tugas dinas dalam menyelenggarakan sebagai urusan pemerintah di bidang tata ruang, bangunan, perumuhan, dan permukiman, air bersih dan teknis penyehatan lingkungan sesuai dengan ketentuan dan/atau peraturan perundang-undangan yang berlaku;

4. Pelaksanaan tugas lain yang diberikan oleh Bupati sesuai dengan tugas dan fungsi Dinas.

Berdasarkan hasil observasi dan pengamatan yang penulis lakukan, beserta pengumpulan data awal, diketahui fenomena yang ada di Dinas Tata Ruang dan Permukiman Kabupaten Cianjur disajikan dalam tabel berikut ini: 
Tabel 1

Tingkat Realisasi Anggaran Tahun 2010 Dinas Tata Ruang dan Permukiman Kabupaten Cianjur

\begin{tabular}{lcccc}
\hline \multirow{2}{*}{ Uraian } & \multicolumn{3}{c}{ Realisasi Per Tri Wulan } \\
\cline { 2 - 4 } & I & I & III & IV \\
\hline Belanja Tidak Langsung (Belanja Pegawai / Gaji dan Tunjangan) & $22,55 \%$ & $54,80 \%$ & $78,40 \%$ & $102,03 \%$ \\
\hline Belanja langsung: & $27,72 \%$ & $46,55 \%$ & $65,16 \%$ & $94,59 \%$ \\
\hline Belanja Pegawai & $8,68 \%$ & $36,54 \%$ & $62,66 \%$ & $73,92 \%$ \\
\hline Belanja Barang Dan Jasa & $8,33 \%$ & $18,79 \%$ & $33,69 \%$ & $72,49 \%$ \\
\hline Belanja Modal & $29,67 \%$ & $48,96 \%$ & $67,71 \%$ & $96,78 \%$ \\
\hline
\end{tabular}

Sumber: Distarkim Kab. Cianjur 2010

Tabel 2

Capaian Kinerja Pegawai Tahun 2010 Dinas Tata Ruang dan Permukiman Kabupaten Cianjur

\begin{tabular}{|c|c|c|c|c|c|c|}
\hline \multirow{2}{*}{ KEG. } & \multirow{2}{*}{ PROGRAM / KEGIATAN } & \multicolumn{4}{|c|}{ CAPAIAN KINERJA PER TRIWULAN } & \multirow{2}{*}{ JUMLAH } \\
\hline & & 1 & 2 & 3 & 4 & \\
\hline I & Program Pelayanan Administrasi Perkantoran & $6 \%$ & $37 \%$ & $18 \%$ & $6 \%$ & $67 \%$ \\
\hline K.1 & Penyediaan Jasa Surat Menyurat & $40 \%$ & $20 \%$ & $10 \%$ & $30 \%$ & $100 \%$ \\
\hline K.2 & Penyediaan Jasa Komunikasi,Sumber Daya Air Dan Listrik & $9 \%$ & $19 \%$ & $15 \%$ & $7 \%$ & $49 \%$ \\
\hline K.3 & Penyediaan Jasa Kebersihan Kantor & $8 \%$ & $25 \%$ & $0 \%$ & $67 \%$ & $100 \%$ \\
\hline K.4 & Penyediaan Alat Tulis Kantor & $50 \%$ & $50 \%$ & $0 \%$ & $0 \%$ & $100 \%$ \\
\hline K.5 & Penyediaan Barang Cetakan Dan Penggandaan & $33 \%$ & $36 \%$ & $30 \%$ & $0 \%$ & $100 \%$ \\
\hline K.6 & Penyediaan Komponen Instalasi Listrik / Penerangan Bangunan Kantor & $8 \%$ & $30 \%$ & $40 \%$ & $22 \%$ & $100 \%$ \\
\hline K.7 & Penyediaan Bahan Bacaan Dan Peraturan Perundang'an & $8 \%$ & $17 \%$ & $22 \%$ & $53 \%$ & $100 \%$ \\
\hline K.8 & Penyediaan Bahan Logistik Kantor & $0 \%$ & $33 \%$ & $11 \%$ & $33 \%$ & $78 \%$ \\
\hline K.9 & Penyediaan Makanan Dan Minuman Kantor & $20 \%$ & $30 \%$ & $20 \%$ & $30 \%$ & $100 \%$ \\
\hline K.10 & Rapat Rapat Koordinasi Dan Konsultasi Ke Luar Daerah & $0 \%$ & $34 \%$ & $7 \%$ & $17 \%$ & $58 \%$ \\
\hline K.11 & Penyediaan Jasa Tenaga Pendukung Administrasi / Teknis Perkantoran & $0 \%$ & $43 \%$ & $21 \%$ & $0 \%$ & $65 \%$ \\
\hline K.12 & Rapat Rapat Koordinasi Dan Konsultasi Ke Dalam Daerah & $43 \%$ & $35 \%$ & $9 \%$ & $13 \%$ & $100 \%$ \\
\hline K.13 & Penyediaan Peralatan Kebersihan Kantor & $33 \%$ & $33 \%$ & $33 \%$ & $0 \%$ & $100 \%$ \\
\hline$\|$ & Program Peningkatan Sarana Dan Prasarana Aparatur & $1 \%$ & $2 \%$ & $68 \%$ & $22 \%$ & $92 \%$ \\
\hline K.14 & Pengadaan Kendaraan Dinas/Operasional & $0 \%$ & $1 \%$ & $92 \%$ & $2 \%$ & $95 \%$ \\
\hline K.15 & Pengadaan Komputer & $0 \%$ & $0 \%$ & $96 \%$ & $4 \%$ & $100 \%$ \\
\hline K.16 & Pengadaan Alat - Alat Kantor & $0 \%$ & $0 \%$ & $100 \%$ & $0 \%$ & $100 \%$ \\
\hline K.17 & Pengadaan Alat -Alat Studio Dan Komunikasi & $0 \%$ & $0 \%$ & $0 \%$ & $100 \%$ & $100 \%$ \\
\hline K.18 & Pemeliharaan Rutin / Berkala Gedung Kantor & $0 \%$ & $0 \%$ & $0 \%$ & $94 \%$ & $94 \%$ \\
\hline K.19 & Pemeliharaan Rutin/Berkala Kendaraan Dinas/Operasional & $3 \%$ & $6 \%$ & $6 \%$ & $42 \%$ & $56 \%$ \\
\hline K.20 & Pemeliharaan Rutin / Berkala Peralatan Gedung Kantor & $27 \%$ & $13 \%$ & $20 \%$ & $40 \%$ & $100 \%$ \\
\hline III & Program Peningkatan Kapasitas Sumberdaya Aparatur & $0 \%$ & $0 \%$ & $0 \%$ & $36 \%$ & $36 \%$ \\
\hline K.21 & Peningkatan Kinerja Aparatur & $0 \%$ & $0 \%$ & $0 \%$ & $36 \%$ & $36 \%$ \\
\hline IV & Program Pengembangan Sistem Pelaporan Capaian Kinerja \& Keuangan & $0 \%$ & $25 \%$ & $30 \%$ & $38 \%$ & $94 \%$ \\
\hline K.22 & Penyusunan Laporan Capaian Kinerja Dan Ikhtisar Realisasi Kinerja Skpd & $0 \%$ & $100 \%$ & $0 \%$ & $0 \%$ & $100 \%$ \\
\hline K.23 & Penyusunan Laporan Keuangan Semesteran & $0 \%$ & $0 \%$ & $22 \%$ & $78 \%$ & $100 \%$ \\
\hline K.24 & Penyusunan Pelaporan Prognosis Realisasi Anggaran & $0 \%$ & $0 \%$ & $100 \%$ & $0 \%$ & $100 \%$ \\
\hline K.25 & Penyusunan Pelaporan Keuangan Akhir Tahun & $0 \%$ & $0 \%$ & $0 \%$ & $74 \%$ & $74 \%$ \\
\hline V & Program Perencanaan Dan Penganggaran & $0 \%$ & $100 \%$ & $0 \%$ & $0 \%$ & $100 \%$ \\
\hline K.26 & Penyusunan Renja Dan Renstra Skpd & $0 \%$ & $100 \%$ & $0 \%$ & $0 \%$ & $100 \%$ \\
\hline K.27 & Penyusunan Rka-Dpa Skpd Dan Rkap-Dppa Skpd & $0 \%$ & $305 \%$ & $-205 \%$ & $0 \%$ & $100 \%$ \\
\hline $\mathrm{VI}$ & Program Pengembangan Kinerja Pengelolaan Air Minum \& Air Limbah & $2 \%$ & $0 \%$ & $5 \%$ & $90 \%$ & $96 \%$ \\
\hline K.28 & Fasilitasi Pembinaan Teknik Pengelolaan Air Minum & $4 \%$ & $3 \%$ & $0 \%$ & $94 \%$ & $100 \%$ \\
\hline
\end{tabular}




\begin{tabular}{|c|c|c|c|c|c|c|}
\hline & & 1 & 2 & 3 & 4 & \\
\hline I & Program Pelayanan Administrasi Perkantoran & $6 \%$ & $37 \%$ & $18 \%$ & $6 \%$ & $67 \%$ \\
\hline K.29 & Operasional Pelayanan Air Minum Non Perpipaan & $4 \%$ & $10 \%$ & $3 \%$ & $82 \%$ & $99 \%$ \\
\hline K.30 & Pengembangan Sistem Penyediaan Air Minum(Spam) Perdesaan & $0 \%$ & $0 \%$ & $0 \%$ & $93 \%$ & $93 \%$ \\
\hline K.31 & Pemeliharaan Sistem Penyediaan Air Minum ( Spam ) Perdesaan ( L-2009 ) & $0 \%$ & $0 \%$ & $0 \%$ & $100 \%$ & $100 \%$ \\
\hline $\mathrm{VII}$ & Program Pembangunan Infrastruktur Pedesaan & $0 \%$ & $1 \%$ & $16 \%$ & $76 \%$ & $92 \%$ \\
\hline K.32 & Penataan Lingkungan Permukiman Penduduk Pedesaan & $0 \%$ & $0 \%$ & $4 \%$ & $90 \%$ & $94 \%$ \\
\hline K.33 & Penataan Lingkungan Permukiman Penduduk Pedesaan(L2009) & $29 \%$ & $14 \%$ & $14 \%$ & $29 \%$ & $86 \%$ \\
\hline K.34 & Pembangunan Prasarana Dan Sarana Air Minum Dan Sanitasi] ( Dak ) & $0 \%$ & $0 \%$ & $30 \%$ & $63 \%$ & $93 \%$ \\
\hline K.35 & Pembangunan Sarana Dan Prasarana Air Minum Dan Sanitasi ( L - 2009 ) & $0 \%$ & $0 \%$ & $0 \%$ & $100 \%$ & $100 \%$ \\
\hline K.36 & Pembangunan Prasarana Dan Sarana Air Minum Dan Sanitasi Pendamping Dak & $0 \%$ & $0 \%$ & $30 \%$ & $49 \%$ & $79 \%$ \\
\hline K.37 & Pembangunan Sarana Dan Prasarana Air Minum Dan Sanitasi ( L - 2009 ) & $1 \%$ & $31 \%$ & $26 \%$ & $39 \%$ & $96 \%$ \\
\hline K.38 & Pembangunan Sistem Penyediaan Air Minum ( Spam ) Pedesaan & $0 \%$ & $0 \%$ & $41 \%$ & $56 \%$ & $97 \%$ \\
\hline K.39 & Pembangunan Sistem Penyediaan Air Minum Pedesaan (L 2009) & $0 \%$ & $0 \%$ & $70 \%$ & $0 \%$ & $70 \%$ \\
\hline K.40 & Pembangunan Sistem Penyediaan Air Minum Ibu Kota Kecamatan (Penunjang Apbn ) & $0 \%$ & $0 \%$ & $12 \%$ & $41 \%$ & $53 \%$ \\
\hline K.41 & Dana Daerah Untuk Pembangunan Bersama ( Ddupb ) lkk & $0 \%$ & $0 \%$ & $0 \%$ & $93 \%$ & $93 \%$ \\
\hline K.42 & Pembangunan Infrastruktur Penunjang Program Kabupaten & $0 \%$ & $0 \%$ & $0 \%$ & $94 \%$ & $94 \%$ \\
\hline VIII & Program Lingkungan Sehat Perumahan & $2 \%$ & $16 \%$ & $9 \%$ & $69 \%$ & $96 \%$ \\
\hline K.43 & Monitoring Evaluasi Dan Pelaporan Bidang Tata Ruang Dan Permukiman & $0 \%$ & $18 \%$ & $44 \%$ & $35 \%$ & $97 \%$ \\
\hline K.44 & Pembangunan Sarana Mck & $0 \%$ & $0 \%$ & $0 \%$ & $95 \%$ & $95 \%$ \\
\hline K.45 & Pembangunan Sarana Mck ( L 2009 ) & $0 \%$ & $0 \%$ & $0 \%$ & $66 \%$ & $66 \%$ \\
\hline K.46 & Pembangunan Sarana Drainase Perkotaan & $0 \%$ & $0 \%$ & $0 \%$ & $92 \%$ & $92 \%$ \\
\hline K.47 & Pembangunan Sarana Drainase Perkotaan ( L 2009 ) & $0 \%$ & $0 \%$ & $100 \%$ & $0 \%$ & $100 \%$ \\
\hline K.48 & Penunjang Pnpm Mandiri Perkotaan ( Pnpm-Mp ) Tahun 2009 Dan 2010 & $5 \%$ & $50 \%$ & $3 \%$ & $42 \%$ & $100 \%$ \\
\hline IX & Program Perbaikan Perumahan Akibat Bencana Alam/Sosial & $0 \%$ & $8 \%$ & $52 \%$ & $15 \%$ & $75 \%$ \\
\hline K.49 & Penanganan Pasca Bencana Alam Tahun 2008 ( L 2009 ) & $0 \%$ & $0 \%$ & $0 \%$ & $0 \%$ & $0 \%$ \\
\hline$K .50$ & Penanggulangan Pasca Bencana Alam Longsor Kabupaten ( L - Apbd ) & $0 \%$ & $8 \%$ & $57 \%$ & $16 \%$ & $81 \%$ \\
\hline $\mathrm{X}$ & Program Peningkatan Kesiagaan Dan Pencegahan Bahaya Kebakaran & $10 \%$ & $13 \%$ & $15 \%$ & $63 \%$ & $100 \%$ \\
\hline K.51 & Penunjang Peningkatan Kesiagaan Dan Pencegahan Bahaya Kebakaran & $10 \%$ & $13 \%$ & $15 \%$ & $63 \%$ & $100 \%$ \\
\hline $\mathrm{XI}$ & Program Perencanaan Tata Ruang & $0 \%$ & $0 \%$ & $0 \%$ & $99 \%$ & $99 \%$ \\
\hline K.52 & Penataan Kawasan Perkotaan Cianjur & $0 \%$ & $0 \%$ & $0 \%$ & $99 \%$ & $99 \%$ \\
\hline $\mathrm{XII}$ & Program Pemamfaatan Ruang & $3 \%$ & $31 \%$ & $10 \%$ & $56 \%$ & $99 \%$ \\
\hline K.53 & Fasilitasi Peningkatan Peran Serta Masyarakat Dalam Pemamfaatan Ruang & $0 \%$ & $31 \%$ & $20 \%$ & $48 \%$ & $99 \%$ \\
\hline K.54 & Monitoring, Evaluasi Dan Pelaporan Pemamfaatan Ruang & $5 \%$ & $31 \%$ & $1 \%$ & $63 \%$ & $100 \%$ \\
\hline $\mathrm{XIII}$ & Program Pengendalian Pemamfaatan Ruang & $0 \%$ & $17 \%$ & $71 \%$ & $3 \%$ & $91 \%$ \\
\hline K.55 & Pengawasan Tata Bangunan & $0 \%$ & $17 \%$ & $71 \%$ & $3 \%$ & $91 \%$ \\
\hline $\mathrm{XIV}$ & Program Pengembangan Kinerja Pengelolaan Persampahan & $13 \%$ & $9 \%$ & $33 \%$ & $9 \%$ & $65 \%$ \\
\hline K.56 & Peningkatan Operasi Dan Pemeliharaan Prasarana Dan Sarana Persampahan & $13 \%$ & $10 \%$ & $37 \%$ & $1 \%$ & $61 \%$ \\
\hline K.57 & Rehabilitasi / Pemeliharaan Dan Penataan Kawasan Tpa & $0 \%$ & $0 \%$ & $6 \%$ & $94 \%$ & $100 \%$ \\
\hline K.58 & Rehabilitasi / Pemeliharaan Dan Penataan Kawasan Tpa ( L 2009 ) & $89 \%$ & $0 \%$ & $0 \%$ & $11 \%$ & $100 \%$ \\
\hline $\mathrm{XV}$ & Program Pengendalian Pencemaran Dan Perusakan Lingkungan Hidup & $24 \%$ & $23 \%$ & $2 \%$ & $27 \%$ & $76 \%$ \\
\hline K.59 & Penunjang Penilaian Kota Sehat / Adipura & $24 \%$ & $23 \%$ & $2 \%$ & $27 \%$ & $76 \%$ \\
\hline $\mathrm{XVI}$ & Program Pengelolaan Ruang Terbuka Hijau & $5 \%$ & $4 \%$ & $10 \%$ & $13 \%$ & $32 \%$ \\
\hline K.60 & Penataan Ruang Terbuka Hijau & $0 \%$ & $0 \%$ & $1 \%$ & $0 \%$ & $1 \%$ \\
\hline K.61 & Penataan Ruang Terbuka Hijau ( L 2009 ) & $0 \%$ & $0 \%$ & $0 \%$ & $0 \%$ & $0 \%$ \\
\hline K.62 & Pemeliharaan Ruang Terbuka Hijau & $10 \%$ & $8 \%$ & $19 \%$ & $25 \%$ & $62 \%$ \\
\hline $\mathrm{XVII}$ & Program Peningkatan Sarana Dan Prasarana Olah Raga & $0 \%$ & $0 \%$ & $0 \%$ & $89 \%$ & $89 \%$ \\
\hline K.63 & Pembangunan Gedung Atlit Dayung Tahap li & $0 \%$ & $0 \%$ & $0 \%$ & $89 \%$ & $89 \%$ \\
\hline $\mathrm{XVIII}$ & Program Peningkatan Sarana \& Prasarana Penyelenggaraan Pemerintah Daerah & $34 \%$ & $22 \%$ & $20 \%$ & $24 \%$ & $100 \%$ \\
\hline K.64 & Pembangunan Gedung Dprd Tahap III ( L 2009 ) & $100 \%$ & $0 \%$ & $0 \%$ & $0 \%$ & $100 \%$ \\
\hline
\end{tabular}




\begin{tabular}{|c|c|c|c|c|c|c|}
\hline & & 1 & 2 & 3 & 4 & \\
\hline I & Program Pelayanan Administrasi Perkantoran & $6 \%$ & $37 \%$ & $18 \%$ & $6 \%$ & $67 \%$ \\
\hline K.65 & Pembangunan Pasar Pasir Hayam & $2 \%$ & $0 \%$ & $85 \%$ & $13 \%$ & $100 \%$ \\
\hline K.66 & Pembangunan Pasar Pasir Hayam ( L 2009 ) & $88 \%$ & $0 \%$ & $0 \%$ & $0 \%$ & $88 \%$ \\
\hline K.67 & Pembangunan Pasar Cipanas & $23 \%$ & $28 \%$ & $21 \%$ & $19 \%$ & $92 \%$ \\
\hline K.68 & Pembangunan Pasar Cipanas ( L 2009 ) & $100 \%$ & $0 \%$ & $0 \%$ & $0 \%$ & $100 \%$ \\
\hline K.69 & Pembangunan Gedung Kwarcab Pramuka Cianjur Tahap li & $0 \%$ & $12 \%$ & $4 \%$ & $78 \%$ & $95 \%$ \\
\hline K.70 & Pembangunan Gedung Kwarcab Pramuka Cianjur Tahap I ( L 2009 ) & $0 \%$ & $0 \%$ & $97 \%$ & $0 \%$ & $97 \%$ \\
\hline K.71 & Pembangunan Gedung Aula,Penembokan Mata Air Dan Mck ( Bksp Dki ) & $0 \%$ & $0 \%$ & $5 \%$ & $90 \%$ & $95 \%$ \\
\hline K.72 & Pembangunan Pasar Desa & $0 \%$ & $1 \%$ & $0 \%$ & $77 \%$ & $78 \%$ \\
\hline K.73 & Pembangunan Kantor Bappeda Kabupaten Cianjur & $0 \%$ & $0 \%$ & $0 \%$ & $90 \%$ & $90 \%$ \\
\hline K.74 & Penyusunan Rencana Detail Tata Ruang Kawasan & $0 \%$ & $0 \%$ & $0 \%$ & $78 \%$ & $78 \%$ \\
\hline K.75 & Ded Tpa Cikalongkulon Kabupaten Cianjur & $0 \%$ & $0 \%$ & $0 \%$ & $97 \%$ & $97 \%$ \\
\hline K.76 & Penyediaan Prasarana \& Sarana Pengelolaan Persampahan & $0 \%$ & $0 \%$ & $0 \%$ & $0 \%$ & $0 \%$ \\
\hline K.77 & Penyediaan Jasa Pengamanan Kantor & $0 \%$ & $0 \%$ & $0 \%$ & $75 \%$ & $75 \%$ \\
\hline K.78 & Penunjang Program Pembangunan Insfrastruktur & $0 \%$ & $0 \%$ & $0 \%$ & $100 \%$ & $100 \%$ \\
\hline
\end{tabular}

Sumber: Bagian SDM Dinas Tata Ruang \& Permukiman Kab. Cianjur, 2010

Berdasarkan tabel 1 dan 2 di atas, terindikasi bahwa kinerja pegawai Dinas Tata Ruang dan Permukiman Kabupaten Cianjur masih belum optimal, karena:

1. Penyelesaian Program kerja terkonsentrasi pada akhir tahun anggaran, sehingga output yang dihasilkan kurang maksimal karena keterbatasan waktu. Hal ini terlihat dari persentase realisasi pada triwulan III masih di bawah $75 \%$, yang normalnya apabila dibagi merata per triwulan itu masing-masing 25\%.

2. Sampai akhir tahun anggaran 2010 realisasi belanja langsung yang merupakan kegiatan yang berhubungan langsung dengan kegiatan pelayanan kepada masyarakat baru mencapai 94,59\% yang artinya masih ada kegiatan yang sudah direncanakan/dianggarkan belum selesai atau tidak terlaksana.

3. Beberapa unit kerja belum maksimal dalam memberikan laporan kinerja yang disebabkan oleh tidak meratanya pembagian tugas.

Masih adanya keluhan dari masyarakat tentang kinerja pegawai yang masih belum optimal dalam memberikan pelayanan, dan adanya program kerja Dinas yang belum sesuai dengan harapan masyarakat.

Selain data tersebut, tabel 3 menyajikan data tentang tingkat kemangkiran pegawai di Dinas Tata Ruang dan Permukiman Kabupaten Cianjur tahun 2010. Berdasarkan data dalam tabel tersebut, diketahui bahwa tingkat kemangkiran pegawai pada bulan Juli 4,32\%, bulan Agustus sebesar 3,76\%, bulan September sebesar
3,12\%, bulan Oktober sebesar 3,70\%, bulan November 3,75\%, dan bulan Desember sebesar 4,06\%. Dengan demikian terlihat dengan jelas pada akhir tahun tingkat kemangkiran pegawai mengalami kenaikan.

\section{Tabel 3}

Tingkat Kemangkiran Pegawai di Dinas Tata Ruang dan Permukiman Kabupaten Cianjur Tahun 2010

\begin{tabular}{lccccc}
\hline \multicolumn{1}{c}{ Bulan } & S.I.A & $\begin{array}{c}\text { SD.OP.IIK. } \\
\text { DIS }\end{array}$ & $\begin{array}{c}\text { Izin } \\
\text { P/L/K }\end{array}$ & \multicolumn{2}{c}{$\begin{array}{c}\text { Persentase } \\
\text { Kehadiran (\%) }\end{array}$} \\
\hline Juli & 83 & 110 & 50 & 3.98 & 96.02 \\
\hline Agustus & 77 & 115 & 52 & 3.76 & 96.24 \\
\hline September & 99 & 108 & 32 & 3.12 & 96.88 \\
\hline Oktober & 85 & 118 & 32 & 3.70 & 96.30 \\
\hline November & 90 & 146 & 34 & 3.75 & 96.25 \\
\hline Desember & 95 & 165 & 48 & 4.06 & 95.94 \\
\hline
\end{tabular}

Sumber: Bagian SDM Dinas Tata Ruang \& Permukiman Kab. Cianjur

Keterangan:

S.I.A = Sakit. Izin. Alpa

SD.OP.IK. DIS = Sakit Dokter. Opname. Izin Khusus. Dispensasi

$\mathrm{P} / \mathrm{L} / \mathrm{K}=$ = Izin Pulang. Terlambat. Keluar

Kinerja pegawai merupakan indikator dari potensi yang dimiliki oleh pegawai dalam melaksanakan tugastugas dan tanggung jawabnya. Kinerja pegawai menunjukkan kesuksesan pegawai dalam melaksanakaan tugas-tugasnya. Kinerja pegawai mempunyai pengaruh yang besar terhadap kinerja Dinas Tata Ruang dan Permukiman Kabupaten Cianjur. Oleh karena itu Dinas Tata 
Ruang dan Permukiman Kabupaten Cianjur terus melakukan berbagai program yang dapat meningkatkan kinerja pegawai, salah satunya dalam meningkatkan kinerja pegawai yaitu dengan kepemimpinan visioner dan pemberdayaan pegawai. Hal tersebut sesuai dengan pendapat Kouzes dan Posner (2004:3), yang mengatakan kepemimpinan adalah penciptaan cara bagi orang untuk ikut berkontribusi dalam mewujudkan sesuatu yang luar biasa. Sementara Wibowo (2008:117) menyatakan bahwa pemberdayaan meningkatkan percaya diri dalam melakukan sesuatu, yang pada waktu sebelumnya tidak pernah percaya, mungkin dilakukan. Bagi organisasi, pemberdayaan akan meningkatkan kinerja organisasi dan individu dapat mengembangkan bakatnya secara penuh.

Kouzes (2004:17), mengatakan bahwa pemimpin adalah vionir sebagai orang yang bersedia melangkah ke dalam situasi yang tidak diketahui. Pemimpin yang mempunyai visi yang jelas dapat menjadi penuntun dalam melaksanakan tugas pokok dan fungsinya sebagai pemimpin. Kartono (2005:51), menyatakan pemimpin adalah seorang pribadi yang memiliki superioritas tertentu, sehingga dia memiliki kewibawaan dan kekuasaan untuk menggerakkan orang lain melakukan usaha bersama guna mencapai sasaran tertentu. Kouzes dan Posner (2004:3), mengatakan kepemimpinan adalah penciptaan cara bagi orang untuk ikut berkontribusi dalam mewujudkan sesuatu yang luar biasa. Boone dan kurtz (1984), yang mengemukakan bahwa kepemimpinan adalah tindakan memotivasi orang lain atau menyebabkan orang lain melakukan tugas tertentu dengan tujuan untuk mencapai tujuan spesifik.

Kepemimpinan visioner adalah kemampuan pemimpin untuk menciptakan dan mengartikulasikan suatu visi yang realistik, dapat dipercaya, atraktif tentang masa depan bagi suatu organisasi atau unit organisasional yang terus bertumbuh dan meningkat sampai saat ini (Robbins, 2001:195). Visi menyalurkan emosi dan energi orang bila diartikulasikan secara tepat, dan sebuah visi menciptakan kegairahan yang menimbulkan energi dan komitmen ditempat kerja. Hal senada dikemukakan oleh Komariah (2005:121) bahwa kepemimpinan visioner (visionary leadership) dapat diartikan sebagai kemampuan pemimpin dalam mencipta, merumuskan, mengkomunikasikan, mensosialisasikan, mentransfor-masikan dan mengimplementasikan pemikiran-pemikiran ideal yang berasal dari dirinya atau sebagai hasil interaksi sosial diantara anggota organisasi dan stakeholders yang diyakini sebagai cita-cita organisasi dimasa depan yang harus dicapai melalui komitmen semua personil.

Kepemimpinan visioner di Dinas Tata Ruang dan Permukiman Kabupaten Cianjur dilaksanakan sesuai dengan visi pembangunan Kabupaten Cianjur dari tahun 2006 sampai dengan 2011, yaitu Terwujudnya Sarana dan Prasarana Lingkungan Perumahan dan Permukiman yang tertata Asri untuk Mendukung terwujudnya Kabupaten Cianjur lebih cerdas, sehat, sejahtera dan berakhlaqul karimah. Dalam visi tersebut termaktub sasaran kebijakan dan program pengembangan Dinas Tata Ruang dan Permukiman Kabupaten Cianjur yang merupakan misi yang harus dilaksanakan antara lain:

1. Meningkatkan Sarana dan Prasarana Air Bersih dan Sanitasi Lingkungan dalam Mewujudkan Kesehatan Lingkungan

2. Meningkatkan Pembangunan Sarana dan Prasarana Lingkungan Permukiman untuk Mendukung Kegiatan Ekonomi Masyarakat

3. Meningkatkan Pelayanan Kepada Masyarakat di Bidang Penataan Ruang dan Permukiman

4. Meningkatkan Peran Serta Masyarakat dalam Mewujudkan Lingkungan Perumahan dan Permukiman yang Bersih dan Sehat.

Dalam kebijakan dan program tersebut, pimpinan di Dinas Tata Ruang dan Permukiman Kabupaten Cianjur harus mampu untuk:

1. Menjelaskan kepada stakeholders. Pemimpin perlu menjelaskan visi dilihat dari segi tindakan-tindakan yang dituntut dan sasaran-sasaran melalui komunikasi lisan dan tertulis yang jelas di Dinas Tata Ruang dan Permukiman Kabupaten Cianjur.

2. Mampu untuk mengungkapkan visi tidak hanya secara verbal melainkan melalui perilaku pemimpin. Ini berarti perilaku pemimpin yang secara berkesinambungan mendorong pencapaian visi Dinas Tata Ruang dan Permukiman Kabupaten Cianjur.

3. Mampu menjabarkan/mewujudkan visi kepada konteks kepemimpinan yang lebih luas, ini berarti merupakan kemampuan untuk mengurutkan aktivitas-aktivitas sehingga visi dapat diterapkan pada berbagai situasi 
pekerjaan di Dinas Tata Ruang dan Permukiman Kabupaten Cianjur.

Berdasarkan tabel 2 mengaenai hasil capaian kinerja terindikasi adanya permasalahan terkait pelaksanaan kepemimpinan visioner, sehingga visi yang sudah buat belum dapat diwujudkan secara optimal.

Selain berkenaan dengan kepemimpinan visioner, pemberdayaan pegawai juga perlu mendapatkan perhatian. Pemberdayaan secara etimologis berasal dari kata daya yang berarti kemampuan untuk melakukan sesuatu atau kemampuan bertindak. Mendapat awalan ber- menjadi 'berdaya' artinya berkekuatan, berkemampuan, bertenaga, mempunyai akal (cara dan sebagainya) untuk mengatasi sesuatu. Mendapat awalan dan akhiran pe-an sehingga menjadi pemberdayaan yang dapat diartikan sebagai usaha/proses menjadikan untuk membuat mampu, membuat dapat bertindak atau melakukan sesuatu (Kamus Besar Bahasa Indonesia 1995).

Menurut Rob Brown (2004:16), pemberdayaan erat hubungannya dengan profesionalisme yang pada awalnya selalu dimiliki oleh individual. Oleh karena itu, pemberdayaan terjadi ketika kekuasaan dimiliki karyawan, maka karyawan akan mengalami rasa kepemilikan dan kontrol atas pekerjaan mereka. Menurut Noe et. al., (2004) pemberdayaan merupakan pemberian tanggung jawab dan wewenang terhadap pekerjaan untuk mengambil keputusan menyangkut semua pengembangan produk dan pengambilan keputusan. Sedangkan Khan (2007:54) menjelaskan pemberdayaan merupakan hubungan antar personal yang berkelanjutan untuk membangun kepercayaan antara pegawai dan manajemen.

Pemberdayaan Pegawai di Dinas Tata Ruang dan Permukiman Kabupaten Cianjur dilaksanakan melalui kewenangan dibidang keciptakaryaan untuk meujudkan Visi yang ditetapkan, Dinas telah menggariskan Kebijakan sebagai acuan atau pedoman atas pelaksanaan programprogram beserta kegiatannya. Adapun kebijakan dalam rangka pemberdayaan pegawai, antara lain ialah sebagai berikut:

1. Memberikan kesempatan yang seluas-luasnya kepada pegawai untuk meningkatkan kemampuannya sesuai dengan kebutuhan kerja yang diemban.

2. Meningkatkan kualitas dan kuantitas pegawai seiring dengan kebutuhan pengembangan organisasi Dinas Tata Ruang dan Permukiman Kabupaten Cianjur.
3. Meningkatkan pelayanan pegawai guna mewujudkan pelayanan yang optimal dibidang keciptakaryaan yang dipersembahkan bagi masyarakat.

4. Meningkatkan kesadaran dan kepedulian masyarakat, khususnya terhadap kegiatan bidang keciptakaryaan, sehingga pegawai akan terlibat dengan baik dengan masyarakat selaku salah satu stakeholders bagi Dinas Tata Ruang dan Permukiman Kabupaten Cianjur.

5. Mewujudkan permukiman yang sesuai dengan daya dukung lingkungan yang menitikberatkan pada kemampuan pegawai Dinas Tata Ruang dan Permukiman Kabupaten Cianjur dalam menghasilkan perencanaan pembangunan yang tepat guna.

6. Meningkatakan kualitas dan kuantitas pemenuhan kebutuhan sarana prasarana fisik dasar wilayah bidang keciptakaryaan dengan melibatkan pegawai Dinas Tata Ruang dan Permukiman Kabupaten Cianjur dalam berbagai proyek pembangunan yang ada dan bagi masyarakat.

7. Berdasarkan latar belakang tersebut, maka penelitian ini dituangkan dalam tema sentral: "Pengaruh Kepemimpinan Visioner dan Pemberdayaan Pegawai terhadap Kinerja Pegawai Dinas Tata Ruang dan Permukiman Kabupaten Cianjur (Studi terhadap Persepsi Pegawai di Lingkungan Distarkim Kab. Cianjur)".

\section{KERANGKA PEMIKIRAN}

Dinas Tata Ruang dan Permukiman merupakan unsur pelaksana otonomi daerah di bidang tata ruang, bangunan, perumahan dan permukiman, air bersih dan teknik penyehatan lingkungan, dipimpin oleh seorang Kepala Dinas yang berada di bawah dan bertanggungjawab kepada Bupati melalui Sekretaris Daerah. Dalam malaksanakan kewenangan dibidang keciptakaryaan untuk meujudkan Visi yang ditetapkan, Dinas telah menggariskan kebijakan sebagai acuan atau pedoman atas pelaksanaan program-program beserta kegiatannya.

Armstrong (2009:4) menyatakan bahwa praktek manajemen sumber daya manusia (SDM) berkaitan dengan semua aspek tentang bagaimana orang bekerja dan dikelola dalam organisasi. Ini mencakup kegiatan seperti strategi SDM, manajemen SDM, tanggung jawab sosial perusahaan, manajemen pengetahuan, pengembangan organisasi, sumber-sumber SDM (perencanaan sumber 
daya manusia, rekrutmen dan seleksi, dan manajemen bakat), manajemen kinerja, pembelajaran dan pengembangan, manajemen imbalan, hubungan pegawai, kesejahteraan pegawai, kesehatan dan keselamatan, serta penyediaan jasa pegawai. Praktek SDM memiliki dasar konseptual yang kuat, yang diambil dari ilmu-ilmu perilaku dan dari manajemen strategis, modal manusia, dan teori hubungan industrial teori. Pemahaman ini telah dibangun dengan bantuan dari berbagai proyek penelitian.

Pernyataan tersebut menegaskan bahwa manajemen sumber daya manusia memberikan pengakuan tentang pentingnya tenaga kerja organisasi sebagai sumber daya manusia utama yang memberi kontribusi bagi pencapaian tujuan-tujuan organisasi serta memberikan kepastian bahwa pelaksanaan fungsi dan kegiatan organisasi dilaksanakan secara efektif dan adil bagi kepentingan individu, organisasi, dan masyarakat.

Organisasi formal, menurut pendapat Sutermeister (1976:21) merupakan hubungan logis yang diatur secara formal dengan ketentuan organisasi. Organisasi ini mempunyai pengaruh vital terhadap kondisi sosial pekerjaan yang pada gilirannya sangat mempengaruhi motivasi kerja. Faktor utama organisasi formal yang sangat berpengaruh terhadap motivasi kerja adalah struktur organisasi, iklim kepemimpinan, efisiensi organisasi, kebijakan personalia, dan komunikasi. Struktur organisasi merupakan gambaran resmi tentang bidang pekerjaan serta lingkup kewenangan dan pengawasan seorang personil dalam hubungannya dengan personil lainnya. Iklim kerja kepemimpinan merupakan hembusan iklim kerja dari pimpinan tertinggi yang sangat berpengaruh terhadap seluruh organisasi termasuk partisipasi. Efisiensi organisasi berkaitan antara lain dengan pembayaran balas jasa yang memadai (respective wages). Kebijakan personalia, meliputi rekrutmen, seleksi, penempatan, pengenalan terhadap pekerjaan, standar kerja dan pelatihan, tingkat gaji dan upah, evaluasi kinerja, insentif dan promosi. Komunikasi berkaitan dengan kegiatan pengembangan saling pengertian untuk mencapai hubungan yang hangat antar personil melalui komunikasi dua arah.

Organisasi informal adalah hasil keseluruhan hubungan pribadi yang terjalin antara individu-individu maupun antara kelompok-kelompok manusia. (Chester I. Bernard dalam Yayat Hayati, 2002:17). Menurut pendapat Chester I. Barnard dalam Hall (1982:47), organisasi informal mempunyai pengaruh dan fungsi yang sangat penting terhadap organisasi formal. Organisasi informal, menurut pendapatnya, dapat membentuk dan menggoyahkan bahkan menghancurkan organisasi formal. Oleh karena itu setiap pimpinan organisasi formal perlu menjaga perkembangan organisasi informal sedemikian rupa sehingga dapat menopang perkembangan organisasi formal.

Faktor lain yang mempengaruhi kondisi kerja organisasi adalah pimpinan organisasi dalam mengatur, menanggapi dan memanipulasi unsur-unsur organisasi. Sehubungan dengan itu, menurut pendapat Sutermeister (1976:74), pimpinan dituntut memiliki karakter ideal dalam "integrity, ambition, drive, loyalty, and judgement". Sejalan dengan pendapat ini, lebih jauh, Zeithaml (2000:4) mengemukakan empat karakteristik keunggulan yang perlu dimiliki oleh pemimpin lembaga yang menyediakan jasa, yaitu "(1) service vision, (2) high standard, (3) in-the-field leadership style, (4) personal integrity". Service vision, artinya bahwa jasa yang berkeunggulan dipandang sebagai strategi laba. High standard diartikan sebagai upaya berkelanjutan untuk meningkatkan keunggulan dan keistimewaan produk yang merupakan pembeda dari produk yang lain. In-the-field leadership style, diartikan bahwa pemimpin memimpin tidak hanya dari meja kerja tetapi mengenali pelaksanaan kerja, melalui observasi, pendengaran, pengajuan pertanyaan, dan cara-cara lain untuk mengembangkan komunikasi dua arah. Personal integrity, dimaksudkan bahwa pemimpin " place a premium on being fair, consistent, and truthful, and as a result earn the trust of associater". Artinya, bahwa pemimpin organisasi mengutamakan keadilan, keajegan, dan kebenaran, sehingga membentuk kepercayaan pihak-pihak yang terkait.

Selain kondisi sosial dan kebutuhan individu, kondisi fisik lingkungan kerja juga dipandang mempunyai peranan yang cukup penting terhadap kenyamanan, ketenangan dan keamanan kerja. Kondisi fisik kerja berkaitan dengan masalah kebisingan, pencahayaan, ventilasi, suhu, keamanan, waktu istirahat, kelembaban dan musik. Mengenai masalah ini, menurut Sutermeister (1976:19), berkaitan erat dengan karakteristik pekerjaan. Sutermeister (1976:19) menyatakan beberapa faktor yang mempengaruhi kondisi fisik lingkungan kerja antara lain: 
lighting, temperature dan ventilation, rest periods, safety, dan music.

Kepemimpinan visioner adalah kemampuan pemimpin untuk menciptakan dan mengartikulasikan suatu visi yang realistik, dapat dipercaya, atraktif tentang masa depan bagi suatu organisasi atau unit organisasional yang terus bertumbuh dan meningkat sampai saat ini (Robbins, 2001:195). Visi menyalurkan emosi dan energi orang bila diartikulasikan secara tepat, dan sebuah visi menciptakan kegairahan yang menimbulkan energi dan komitmen ditempat kerja. Komariah (2005:121) menyatakan bahwa kepemimpinan visioner (visionary leadership) dapat diartikan sebagai kemampuan pemimpin dalam mencipta, merumuskan, mengkomunikasikan, mensosialisasikan, mentransformasikan dan meng-implementasikan pemikiran-pemikiran ideal yang berasal dari dirinya atau sebagai hasil interaksi sosial diantara anggota organisasi dan stakeholders yang diyakini sebagai cita-cita organisasi dimasa depan yang harus dicapai melalui komitmen semua personil.

Pemberdayaan pegawai di Distarkim Kab. Cianjur diduga belum dilaksanakan dengan optimal, padahal pemberdayaan pegawai merupakan salah satu hal yang paling penting untuk menciptakan PNS yang memiliki kinerja yang maksimal. Untuk itu, pemberdayaan pegawai merupakan salah satu langkah strategis dalam menciptakan PNS yang profesional. Hal tersebut sesuai dengan pendapat Rob Brown (2004:16), yang menyatakan bahwa pemberdayaan erat hubungannya dengan profesionalisme yang pada awalnya selalu dimiliki oleh individual. Oleh karena itu empowerment terjadi: "When power goes to employees who then experience a sense of ownership and control over".

Noe et. al., (2004) menyatakan bahwa pemberdayaan merupakan pemberian tanggung jawab dan wewenang terhadap pekerjaan untuk mengambil keputusan Menyangkut semua pengembangan produk dan pengambilan keputusan. Sedangkan Kahn (2007) menjelaskan pemberdayaan merupakan hubungan antar personal yang berkelanjutan untuk membangun kepercayaan antara pegawai dan manajemen. Pemberdayaan pegawai terdiri dari serangkaian proses, antara lain: a) Desire, Tahap pertama dalam model empowerment adalah adanya mendelegasikan dan melibatkan pekerja; b) Trust, Setelah adanya keinginan dari manajemen untuk melakukan pemberdayaan, langkah selanjutnya adalah membangun kepercayaan antara manajemen dan pegawai. adanya saling percaya diantara anggota organisasi akan tercipta kondisi yang baik untuk pertukaran informasi dan saran adanya rasa takut; c) Confident, Langkah selanjutnya setelah adanya saling percaya adalah menimbulkan rasa percaya diri pegawai dengan menghargai terhadap kemampuan yang dimiliki oleh pegawai; d) Credibility, Langkah keempat menjaga kredibilitas dengan penghargaan dan mengembangkan lingkungan kerja yang mendorong kompetisi yang sehat sehingga tercipta organisasi yang memiliki kinerja yang tinggi; e) Accountability, Tahap dalam proses pemberdayaan selanjutnya adalah pertanggungjawaban pegawai pada wewenang yang diberikan dengan menetapkan secara konsisten dan jelas tentang peran, standar, dan tujuan tentang penilaian terhadap kinerja pegawai, tahap ini sebagai sarana evaluasi terhadap kinerja pegawai dalam penyelesaian dan tanggung jawab terhadap wewenang yang diberikan; dan f) Communication, Langkah terakhir adalah adanya komunikasi yang terbuka untuk menciptakan saling memahami antara pegawai dan manajemen. Keterbukaan ini dapat diwujudkan dengan adanya kritik dan saran terhadap hasil dan prestasi yang dilakukan pekerja.

Kinerja adalah hasil kerja secara kualitas dan kuantitas yang dicapai oleh seorang pegawai dalam melaksanakan tugasnya sesuai dengan tanggung jawab yang diberikan kepadanya (Mangkunegara, 2007:67). Gomes (1995:195) menyatakan kinerja pegawai sebagai ungkapan seperti output, efesiensi serta efektivitas sering dihubungkan dengan produktivitas. Dapat disimpulkan bahwa kinerja sumber daya manusia adalah prestasi atau hasil kerja (output) baik kualitas maupun kuantitas yang dicapai sumner daya manusia persatuan periode waktu dala melaksanakan tugas kerjanya sesuai dengan tanggung jawab yang diberikan kepadanya. Mangkunegara (2007:17), membagi aspek-aspek kinerja atau ukuran dalam kinerja sebagai berikut: a) Mutu kerja; b) Kejujuran pegawai; c) Inisiatif; d) Kehadiran; e) Sikap; f) Kerjasama; g) Keandalan; h) Pengetahuan tentang pekerjaan; i) Tanggung jawab; dan j) Pemanfaatan waktu.

Berdasarkan kerangka teoritis tersebut, diketahui bahwa dua variabel yang memberikan kontribusi terhadap tinggi rendahnya kinerja pegawai di Distarkim Kab. Cianjur, 
yaitu kepemimpinan visioner dan pemberdayaan pegawai, untuk itu kedua variabel tersebut menjadi variabel independen yang diteliti dalam penelitian ini. Selanjutnya kerangka pemikiran dalam penelitian ini disajikan dalam Gambar berikut:

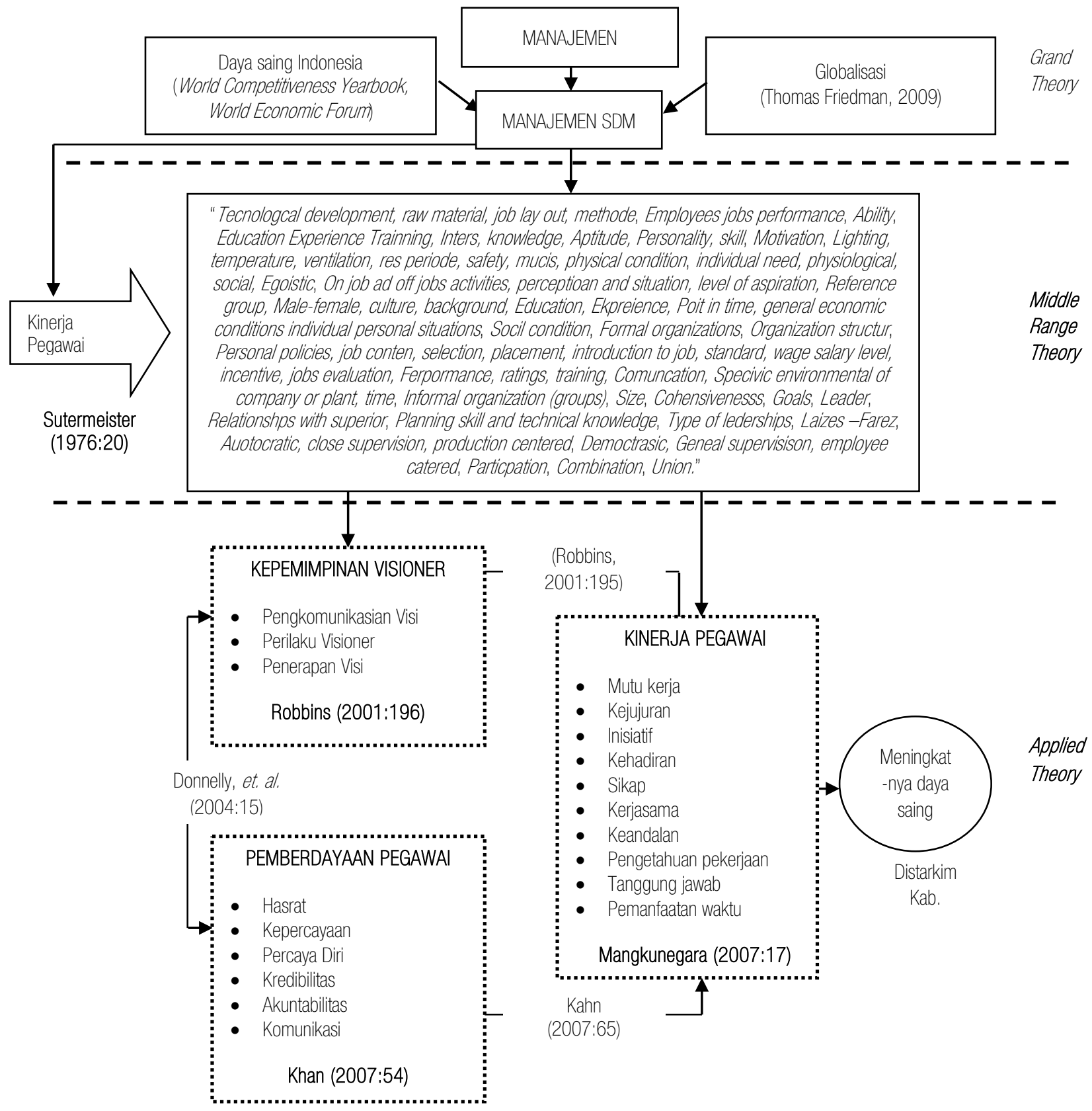

\section{Gambar 1 \\ Kerangka Pemikiran}

Sumber: Modifikasi dari Sutermeister (1976:14); Robbins (2001:196); Khan (2007:54); dan Mangkunegara (2007:17).

Model paradigma penelitian yang menerangkan pengaruh kepemimpinan visioner dan pemberdayaan pegawai terhadap kinerja pegawai di Distarkim Kab. Cianjur disajikan pada gambar berikut ini. 


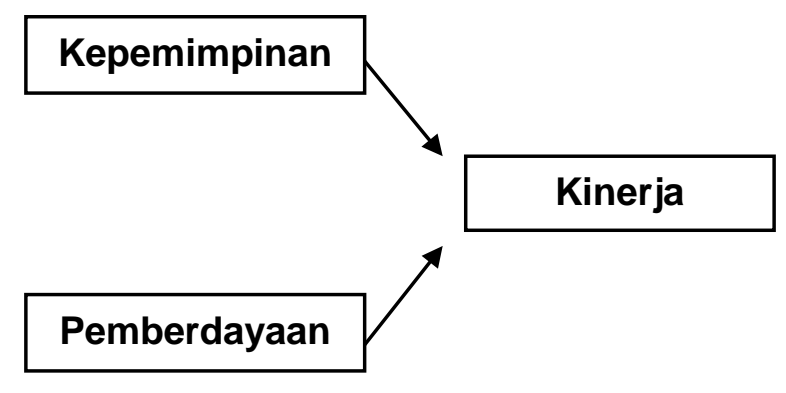

Gambar 2

Paradigma Penelitian

\section{Perumusan Hipotesis}

Menurut Suharsimi Arikunto (2006:71), hipotesis merupakan suatu jawaban yang bersifat sementara terhadap permasalahan penelitian sampai terbukti melalui data yang terkumpul. Berdasarkan rumusan masalah dan kerangka pemikiran yang telah tersusun, maka hipotesis penelitian ini ialah:

1. Kepemimpinan visioner berpengaruh positif dan signifikan terhadap kinerja pegawai di Distarkim Kab. Cianjur.

2. Pemberdayaan pegawai berpengaruh positif dan signifikan terhadap kinerja pegawai di Distarkim Kab. Cianjur.

3. Kepemimpinan visioner dan pemberdayaan pegawai berpengaruh positif dan signifikan terhadap kinerja pegawai di Distarkim Kab. Cianjur.

\section{METODOLOGI PENELITIAN}

Penelitian ini bersifat deskriptif dan verifikatif.

maka metode penelitian yang digunakan adalah metode descriptive survey dan metode explanatory survey. Populasi dalam penelitian ini adalah pegawai di lingkungan Distarkim Kab. Cianjur yang berjumlah 167 Pegawai. Berdasarkan hasil perhitungan sampel, diperoleh unit analisis sebesar 118 sampel. Untuk menentukan sampel yang akan digunakan dalam peneltian, digunakan teknik simple random sampling (SRS).

Adapun rumus validitas yang digunakan adalah rumus Korelasi Product Moment, sedangkan rumus reliabilitas yang digunakan untuk mengukur reliabilitas adalah teknik split half dari Spearman Brown. Karena penelitian ini menganalisis lebih dari dua variabel, maka digunakan teknik analisis regresi linier berganda.

\section{HASIL PENELITIAN}

Tabel 4

Rekapitulasi Frekuensi Jawaban Responden tentang Kepemimpinan Visioner di Distarkim Kab.

Cianjur

\begin{tabular}{|c|c|c|}
\hline Klasifikasi & Frekuensi & $\%$ \\
\hline Sangat Tinggi & 588 & 33,22 \\
\hline Tinggi & 902 & 50,96 \\
\hline Cukup Tinggi & 252 & 14,24 \\
\hline Rendah & 26 & 1,47 \\
\hline Sangat Rendah & 2 & 0,11 \\
\hline Jumlah & 1770 & 100 \\
\hline
\end{tabular}

Tabel 5

Rekapitulasi Tanggapan Responden tentang Kepemimpinan Visioner di Distarkim Kab. Cianjur

\begin{tabular}{cccc}
\hline No & $\begin{array}{c}\text { Dimensi } \\
\text { Kepemimpinan } \\
\text { Visioner }\end{array}$ & $\begin{array}{c}\text { Perolehan } \\
\text { Skor }\end{array}$ & $\begin{array}{c}\text { Persentase } \\
(\%)\end{array}$ \\
\hline 1. & Pengkomunikasian Visi & 2002 & 27,20 \\
\hline 2. & Perilaku Visioner & 2428 & 33,00 \\
\hline 3. & Perwujudan Visi & 2928 & 39,80 \\
\hline & Total & 7358 & 100 \\
\hline
\end{tabular}

Sumber : Hasil Pengolahan Data Tahun 2011

Tabel 6

Uji Signifikan

\begin{tabular}{cccc}
\multicolumn{4}{c}{ dengan Perbandingan Nilai $\mathbf{t}_{\text {tabel }}$ dan $\mathbf{t}_{\text {hitug }}$} \\
\hline Variabel & $t_{\text {hitung }}$ & $t_{\text {tabel }}$ & Simpulan \\
\hline Kepemimpinan Visioner & 4,309 & 1,676 & Hipotesis Diterima \\
\hline Pemberdayaan Pegawai & 4,405 & 1,676 & Hipotesis Diterima
\end{tabular}

Sumber : Hasil Pengolahan Data 2011

\section{Tabel 7}

Uji F dan Signifikan

\begin{tabular}{|c|c|c|c|c|c|}
\hline \multicolumn{6}{|c|}{ ANOVA $^{\mathrm{b}}$} \\
\hline Model & $\begin{array}{l}\text { Sum of } \\
\text { Squares }\end{array}$ & df & $\begin{array}{l}\text { Mean } \\
\text { Square }\end{array}$ & F & Sig. \\
\hline 1 Regression & 5928.192 & 2 & 2964.096 & 170.540 & $.000^{2}$ \\
\hline Residual & 4832.294 & 115 & 42.020 & & \\
\hline Total & 10760.486 & 117 & & & \\
\hline
\end{tabular}

a. Predictors: (Constant), Pemberdayaan Pegawai, Kepemimpinan Visioner

b. Dependent Variable: Kinerja Pegawai

Sumber : Hasil Pengolahan Data 2011 
Tabel 8

Koefisien Regresi

\begin{tabular}{|c|c|c|c|c|}
\hline \multicolumn{5}{|c|}{ Coefficients $^{a}$} \\
\hline \multirow{2}{*}{ Model } & \multicolumn{2}{|c|}{$\begin{array}{c}\text { Unstandardized } \\
\text { Coefficients }\end{array}$} & $\begin{array}{l}\text { Standardized } \\
\text { Coefficients }\end{array}$ & \multirow{2}{*}{ Sig. } \\
\hline & B & $\begin{array}{l}\text { Std. } \\
\text { Error }\end{array}$ & Beta & \\
\hline 1 (Constant) & 87.340 & 3.957 & & 4.382 .000 \\
\hline $\begin{array}{l}\text { Kepemimpinan } \\
\text { Visioner }\end{array}$ & .253 & .173 & .256 & 4.309 .000 \\
\hline $\begin{array}{l}\text { Pemberdayaan } \\
\text { Pegawai }\end{array}$ & .393 & .112 & .594 & 4.405 .000 \\
\hline \multicolumn{5}{|c|}{ a. Dependent Variable: Kinerja Pegawai } \\
\hline
\end{tabular}

Sumber : Hasil Pengolahan Data 2011

Tabel 9

Uji Signifikan

dengan Perbandingan Nilai $t_{\text {tabel }}$ dan $t_{\text {hitug }}$

\begin{tabular}{lccl}
\hline \multicolumn{1}{c}{ Variabel } & $t_{\text {nitung }}$ & $t_{\text {tabel }}$ & $\begin{array}{l}\text { Simpulan } \\
\text { Hipotesis }\end{array}$ \\
\hline $\begin{array}{l}\text { Kepemimpinan } \\
\text { Visioner }\end{array}$ & 4,309 & 1,676 & Diterima \\
\hline $\begin{array}{l}\text { Pemberdayaan } \\
\text { Pegawai }\end{array}$ & 4,405 & 1,676 & Diterima \\
\hline
\end{tabular}

Sumber : Hasil Pengolahan Data 2011

Tabel 10

Koefisien Determinasi

\begin{tabular}{|c|c|c|c|c|}
\hline \multicolumn{5}{|c|}{ Model Summary } \\
\hline Model & R & $\begin{array}{c}\mathrm{R} \\
\text { Square }\end{array}$ & $\begin{array}{l}\text { Adjusted R } \\
\text { Square }\end{array}$ & $\begin{array}{l}\text { Std. Error of the } \\
\text { Estimate }\end{array}$ \\
\hline 1 & $.839^{a}$ & .703 & .735 & 6.492 \\
\hline \multicolumn{5}{|c|}{$\begin{array}{l}\text { a. Predictors: (Constant), Kepemimpinan Visioner, } \\
\text { Pemberdayaan Pegawai }\end{array}$} \\
\hline
\end{tabular}

\section{PEMBAHASAN}

\section{Pengaruh Kepemimpinan Visioner terhadap Kinerja Pegawai}

Persamaan regresi linier sederhana antara kepemimpinan visioner dan kinerja pegawai ialah sebagai berikut: $\hat{Y}=14,632+0,727 X_{1}$. Pengujian signifikansi konstanta dapat dilakukan dengan membandingkan nilai t tabel dengan harga $t_{\text {hitung, }}$ untuk taraf kesalahan $5 \%$ uji satu pihak dengan $\mathrm{dk}=\mathrm{n}-2$, maka diperoleh $\mathrm{t}$ tabel sebesar 1,676. Karena nilai $t_{\text {hitung }}$ lebih besar dari pada $t{ }_{\text {tabel }}$ $(10,540>1,676)$, maka hipotesis diterima. Hal ini berarti terdapat pengaruh positif dan signifikan dari kepemimpinan visioner terhadap kinerja pegawai. Kekuatan hubungan kepemimpinan visioner dengan kinerja pegawai berada pada kisaran yang tinggi. Kontribusi dari kepemimpinan visioner sebagai variabel bebas atau variabel yang mempengaruhi terhadap kinerja pegawai sebesar 38,5\%, dan sisanya sebesar 61,5\% dipengaruhi oleh faktor lain yang tidak diteliti dalam penelitian ini.

\section{Pengaruh Pemberdayaan Pegawai terhadap Kinerja Pegawai}

Persamaan regresi linier sederhana antara komitmen organsiasional dan kinerja pegawai ialah sebagai berikut: $\hat{Y}=16,645+0,471 X_{2}$. Pengujian signifikansi konstanta dapat dilakukan dengan membandingkan nilai $t$ tabel dengan harga $t_{\text {hitung, }}$ untuk taraf kesalahan $5 \%$ uji satu pihak dengan $\mathrm{dk}=\mathrm{n}-2$, maka diperoleh $\mathrm{t}_{\text {tabel }}$ sebesar 1,676. Karena nilai $t_{\text {hitung }}$ lebih besar dari pada $t_{\text {tabel }}(8,152$ $>1,676)$, maka hipotesis diterima. Hal ini berarti terdapat pengaruh positif dan signifikan dari pemberdayaan pegawai terhadap kinerja pegawai. Kekuatan hubungan pemberdayaan pegawai dengan kinerja pegawai berada pada kisaran yang kuat. Kontribusi dari pemberdayaan pegawai sebagai variabel bebas atau variabel yang mempengaruhi terhadap kinerja pegawai sebesar 56,7\%, dan sisanya sebesar 43,3\% dipengaruhi oleh faktor lain yang tidak diteliti dalam penelitian ini.

\section{Pengaruh Kepemimpinan Visioner dan Pemberdayaan Pegawai terhadap Kinerja Pegawai}

Hasil pengujian $F$ dan signifikansi, dapat diketahui besarnya $F$ hitung melalui uji ANOVA atau $F$ test, yaitu sebesar 170,540 dengan tingkat signifikansi sebesar 0,000 . Karena probabilitas $(0,000)$ jauh lebih kecil dari 0,05, maka model regresi ini bisa dipakai untuk memprediksi kinerja pegawai atau dapat disimpulkan bahwa kepemimpinan visioner dan pemberdayaan pegawai berpengaruh terhadap kinerja pegawai. Persamaan regresi linier berganda ialah sebagai berikut: $\hat{Y}=87,340+$ $0,253 X_{1}+0,393 X_{2}$

Pengujian signifikansi konstanta dapat dilakukan dengan membandingkan nilai $t_{\text {tabel }}$ dengan harga $t_{\text {hitung' }}$ untuk taraf kesalahan 5\% uji satu pihak dengan dk =n-2, maka diperoleh $t_{\text {tabel }}$ sebesar 1,676. Berdasarkan uji signifikansi diketahui bahwa terdapat pengaruh yang positif dan signifikan dari kepemimpinan visioner dan pemberdayaan pegawai terhadap kinerja pegawai. 
Kekuatan hubungan kepemimpinan visioner dan pemberdayaan pegawai dengan kinerja pegawai berada pada kisaran yang sangat kuat. Kontribusi kepemimpinan visioner dan pemberdayaan pegawai sebagai variabel bebas atau variabel yang mempengaruhi terhadap kinerja pegawai sebesar 70,3\%, dan sisanya sebesar 29,7\% dipengaruhi oleh faktor lain yang tidak diteliti dalam penelitian ini, misalnya budaya organisasi, kompetensi kerja pegawai, dan pelatihan kerja.

\section{KESIMPULAN}

1. Kepemimpinan visioner, pemberdayaan pegawai, dan kinerja pegawai di Distarkim Kab. Cianjur termasuk dalam klasifikasi yang tinggi.

2. Kepemimpinan visioner berpengaruh positif dan signifikan terhadap kinerja pegawai di Distarkim Kab. Cianjur.

3. Pemberdayaan pegawai berpengaruh positif dan signifikan terhadap kinerja pegawai di Distarkim Kab. Cianjur.

4. Kepemimpinan visioner dan pemberdayaan pegawai berpengaruh positif dan signifikan terhadap kinerja pegawai di Distarkim Kab. Cianjur.

\section{REKOMENDASI}

1. Kepemimpinan visioner di Distarkim Kab. Cianjur termasuk dalam klasifikasi skor tinggi namun belum optimal dalam meningkatkan kinerja pegawai. Untuk itu, pengkomunikasian visi, perilaku visioner, dan perwujudan visi perlu dioptimalkan. Skor paling rendah diperoleh pengkomunikasian visi, untuk itu pengkomunikasian visi bisa lebih dioptimalkan lagi misalnya dengan membuat bulletin atau majalah sehingga pemimpin bisa lebih baik lagi dalam mengkomunikasian visinya.

2. Pemberdayaan pegawai di Distarkim Kab. Cianjur termasuk dalam klasifikasi skor tinggi namun belum optimal dalam meningkatkan kinerja pegawai. Untuk itu hasrat, kepercayaan, percaya diri, kredibilitas, akuntabilitas, dan komunikasi perlu dioptimalkan. Skor paling rendah diperoleh komunikasi, untuk itu komunikasi perlu lebih dioptimalkan lagi, misalnya dengan sering melakukan diskusi formal melalui forum curah pendapat, dan diskusi nonformal misalnya melalui komunikasi pada saat berwisata.

3. Kinerja pegawai di Distarkim Kab. Cianjur termasuk dalam klasifikasi skor tinggi namun belum optimal. Untuk itu mutu kerja, kejujuran, inisiatif, kehadiran, sikap, kerjasama, keandalan, pengetahuan pekerjaan, tanggung jawab, dan pemanfaatan waktu. Skor paling rendah diperoleh pemanfaatan waktu, untuk itu pemanfaatan waktu perlu dioptimalkan lagi oleh para pegawai di lingkungan Distarkim Kab. Cianjur, misalnya membuat perencanaan kerja dan fokus pekerjaan yang lebih matang lagi dengan mempertimbangkan kemampuan dan kompetensi kerja yang dimiliki pegawai.

4. Dibandingkan dengan pemberdayaan pegawai, kepemimpinan visioner mempengaruhi kinerja pegawai lebih rendah. Untuk itu, maka kepemimpinan visioner harus lebih dioptimalkan.

\section{DAFTAR PUSTAKA}

Aan Komariah, 2005. Kepemimpinan Kepal Sekolah. Bandung: CV. Alfabeta.

Anwar Prabu Mangkunegara. 2006. Manajemen Sumber Daya Manusia. Bandung: Refika Aditama.

Armstrong, Michael. 2009. Armstrong's Handbook of Human Resource Management Practice, $11^{\text {th }}$ edition. United Kingdom: Kogan Page.

Boone dan Kurtz, 1984. Business. New York: Princtice Hall.

Brown, Rob. 2004. Leadership. England: Kogan Page.

Depdikbud. 1995. Kamus Besar Bahasa Indonesia. Jakarta: Balai Bahasa-Balai Pustaka.

Gomes, Faustino Cardoso. 2003. Manajemen Sumber Daya Manusia, Edisi Kedua. Yogyakarta: Andi Offset.

Hall, Richard. 1982. Organizations. New York: Kogan Page.

Hayati, Yayat. 2002. Perilaku Organisasi. Bandung: CV. Alfabeta.

Kartono, Kartini. 2005. Kepemimpinan: Apakah Kepemimpinan Abnormal itu? Jakarta: PT. Raja Grafindo Persada.

Khan, S. 2007. The Key Being a Leader Company Empowerment. Journal for Quality and Participation. New Jersey. 
Kouzes M. James \& Posner Z. Barry. 2004. Kridibilitas.

(Terjemahan). Professional Books. Jakarta.

Noe, Raymond A., John R. Hollenbeck, Barry Gerhart, and

Patrick M. Wright. 2004. Human Resource

Management, Gaining Competitive Advantage, $3^{\text {rd }}$ Edition. McGraw-Hill.

Robbins, Stephen P.. 2001. Budaya Organisasi, Jakarta: Salemba Empat.

Suharsimi Arikunto. 2006. Prosedur Penelitian Suatu Pendekatan Praktek. Jakarta: Rineka Cipta.

Sutermeister, Robert A. 1976. People and Productivity. New Jersey: Mcgraw-Hill.

Wibowo. 2008. Manajemen Kinerja. Jakarta: PT. Raja Grafindo Persada. 